The implication is that caution should be exercised in ascribing anthracnose of olives to $G$. olivarum $\mathrm{Alm}$.

Department of Agriculture, G. J. M. A. Gorter

Pretoria.

Aug. 6.

1 Almeida, J. V. d', Bull. Soc. Myc. France, 15, 90 (1899).

${ }^{2}$ Hemmi, T., and Kurata, S., J. Soc. Trop. Agric. Taiwan, 6, 573 (1935).

${ }^{3}$ Ciccarone, A., Boll. del Staz. di Pat. Veg., 5, Serie 5, 143 (1947).

4 Pontis, R. E., and Hansen, H. N., Phytopath., 32, 642 (1942)

${ }^{5}$ Andes, J. O., and Keitt, G. W., Phytopath., 40, 915 (1950).

${ }_{6}^{6}$ Strubble, F. B., and Keitt, G. W., Amer, J. Bot., 37, 563 (1950)

' Edgerton, C. W., Phytopath., 5, 247 (1915).

8 Ramsey, G. B., Smith, M. A., and Heiberg, B. C., Phytopath., 41, 447 (1951).

\section{Etiology of European Foul Brood; a Disease of the Larval Honey-bee}

THE cause of European foul brood was originally thought to be Bacillus alve $i^{1}$ or a mixture of $B$. alvei and Streptococcus apis ${ }^{2}$. The causative organism was later named and described by White $^{3}$ as Bacillus pluton, a lanceolate Gram-positive bacterium. 'This organism is the first of several which have been found to appear in diseased larvæ. However, White and others failed to culture $B$. pluton in vitro and it was afterwards considered to be a dissociant form of Bacillus alvei $i^{4}$, of Bacterium eurydice ${ }^{5}$, or of both ${ }^{6}$. Others ${ }^{7,8}$ have maintained that $B$. pluton is a separate organism. It has been pointed out that Streptococcus pluton would be a more suitable designation than Bacillus pluton both on morphological grounds and in the absence of evidence that it forms spores. For these reasons and those given below the organism will be referred to as Streptococcus pluton.

Attempts have recently been made, by Prof. L. P. Garrod (St. Bartholomew's Hospital), to cultivate S. pluton, from diseased larvæ ${ }^{9}$. A Gram-positive encapsulated, pleomorphic, usually oval coccus which grew in anaerobic conditions on glucose-broth agar, was repeatedly isolated from diseased larvæ. Some evidence was obtained on one occasion that this bacterium grew in honey-bee larvæ and developed. into an organism morphologically identical with $S$. pluton, but the disease failed to develop in this and in repeated experiments.

During further attempts to re-isolate the organism on special media, I have recently been able to isolate a bacterium which is probably the same as that previously isolated by Garrod; but its growth is relatively much stronger, and it is now morphologically stable. It appears to be S. pluton. The organism can readily be isolated in anaerobic conditions on a medium composed of : 1 per cent yeast extract ('Difco' yeast extract is very suitable); l per cent glucose; 0.1 molar potassium dihydrogen phosphate; 2 per cent agar. Adjust to $p H \mathbf{H} 6.5$ with concentrated potassium hydroxide. Sterilize by steaming or in the autoclave at 5 -lb. pressure $\left(108^{\circ} \mathrm{C}\right.$.).

The optimum temperature for growth is about $35^{\circ} \mathrm{C}$. The optimum $p \mathrm{H}$ is about 6.5 ; no growth occurs at or below $p \mathrm{H} 5 \cdot \tilde{5}$. The colonies are small (never more than about $1.5 \mathrm{~mm}$. in diameter), round, entire and convex. They are transparent and microscopic after $24 \mathrm{hr}$, just visible and granular after $48 \mathrm{hr}$, and become very granular and pearly white by reflected light and almost opaque and slightly brown by transmitted light after three days. The organism grows as a lanceolate Streptococcus in chains of variable lengths. It has a thick cell wall, is highly refractile in watery suspension and is Gram-positive. Carbohydrate is essential ; but only glucose, fructose or, to a lesser extent, sucrose support growth. Neither acid nor carbon dioxide is formed in detectable amounts. Citrate strongly inhibits growth and can be counteracted by magnesium. Marked inhibition of growth is caused if the ratio $\left[\mathrm{Na}^{+}\right] /\left\llcorner\mathrm{K}^{+}\right]$is greater than 1 ; virtually no growth occurs if $\mathrm{K}^{+}$is entirely replaced (apart from the normal traces in the constituents of the medium) by $\mathrm{Na}^{+}$. Carbon dioxide stimulates growth. Oxygen is normally tolerated up to a concentration of about 1 per cent; but growth is then weak and apparently involuted with individual cocci poorly differentiated to give chains with a more rod-like appearance.

Invariably, with the numerous isolates made so far of $S$. pluton, there have appeared colonies of Bacterium eurydice. The colonies of the latter have always been the first to appear, and its cultural characteristics agree with those given in detail by Gubler $^{8}$. The two organisms will readily subculture together in mixed culture in anaerobic conditions on the medium described above. These mixed cultures (fifth subcultures) have repeatedly produced acute and extensive European foul brood when sprayed on the combs of brood in healthy bee colonies. The two organisms have always been re-isolated from the diseased larvie of these colonies. Virulence seems to diminish markedly in subculture.

$B$. eurydice alone does not cause the disease, as previous workers have also shown. S. pluton in pure culture also has not usually caused the disease; the bacteria have appeared to grow vigorously in young larvæ but have disappeared in older larvæ after producing forms suggestive of the involuted types obtained in culture in relatively high oxygen tensions. On a few occasions an initially mild attack of the disease affecting very few larvæ has arisen after infection with pure cultures of $S$. pluton. However, $B$. eurydice was also seen to be present in the diseased larvæ and was always isolated, as usual, with S. pluton.

No evidence has been obtained to support the theory $^{5}$ that $B$. eurydice dissociates into $S$. pluton; but it seems that the presence of both bacteria is necessary for the disease to appear. The appearance of $B$. eurydice in those larva which have shown disease after infection with pure cultures of $S$. pluton suggests that it was already present in the bees. This supports the findings of Burri $^{5}$ and Gubler ${ }^{8}$ that $B$. eurydice can occur in colonies of healthy bees. However, its occurrence does not appear to be widespread; at least not in the locality where the experiments reported here were carried out.

Further work on the symbiotic relationships between $B$. eurydice and $S$. pluton and upon the epidemiology and control of the disease is in progress and will be reported in more detail in due course.

L. BAILEY

Rothamsted Experimental Station, Harpenden, Herts. Aug. 13.

${ }^{1}$ Cheshire, F. R., and Cheyne, W. W., J. Roy. Micro. Soc., 5, 581 (1885). 2 Maassen, A., Arb. Biol. Abt. (Anst.-Reichsanst.) Berl., 6, 53 (1908). 3 White, G. F., Bull. U.S. Bur. Ent., No. 157 (1912).

${ }^{4}$ Lochhead, A. G., Sci. Agric., 9, 80 (1928).

5 Burri, R., Beih. Schweiz. Bienenztg., 1, 209 (1943).

- Burnside, C. E., J. Econ. Ent., 27, 656 (1934).

7 Tarr, H. L. A., Ann. App. Biol., 25, 815 (1938).

${ }^{8}$ Gubler, H. U., Schweiz. Z, Allg. Path., 17, 507 (1954).

- Rep. Rothamsted Exp. Sta., 136. (1954). 